339.924(477):061.1€C]:339.548(470+571)

\title{
QUANTITATIVE ANALYSIS OF TRADE COMPLEMENTARITY BETWEEN UKRAINE AND THE EU
}

\section{КІЛЬКІСНИЙ АНАЛІЗ КОМПЛІМЕНТАРНОСТІ ТОРГІВЛІ МІЖ УКРАЇНОЮ ТА КРАЇНАМИ ЄС}

\section{КОЛИЧЕСТВЕННЫЙ АНАЛИЗ КОМПЛИМЕНТАРНОСТИ ТОРГОВЛИ МЕЖДУ УКРАИНОЙ И СТРАНАМИ ЕС}

\section{Shnyrkov O. I.}

Doctor of Economic Sciences, Professor, Head of the Department of World Economy and International Economic Relations of Taras Shevchenko National University of Kyiv. E-mail: aisch@ukr.net

\section{Pliushch D. S.}

$\mathrm{PhD}$ (Economics) of Institute of International Relations of Taras Shevchenko National University of Kyiv. E-mail: d.pliushch@gmail.com

\section{Шнирков О. I.}

Доктор економічних наук, професор, завідувач кафедри світового господарства і міжнародних економічних відносин Інституту міжнародних відносин Київського національного університету імені Тараса Шевченка. Еmail: aisch@ukr.net

\section{Плющ Д. С.}

Аспірант кафедри світового господарства і міжнародних економічних відносин Інституту міжнародних відносин Київського національного університету імені Тараса Шевченка. E-mail: d.pliushch@ gmail.com

\section{Шнырков А. И.}

Доктор экономических наук, профессор, заведующий кафедрой мирового хозяйства и международных экономических отношений Института международных отношений Киевского национального университета имени Тараса Шевченко. E-mail: aisch@ukr.net

\section{Плющ Д. С.}

Аспирант кафедры мирового хозяйства и международных экономических отношений Института международных отношений Киевского национального университета имени Тараса Шевченко. Е-таil: d.pliushch@gmail.com

Abstract. The article outlines the perspective benefits of deepening integration processes between Ukraine and the European Union. Groups of Ukrainian goods have been identified, which exports to the EU are increasing dynamically. EU countries have been identified in which exports from Ukraine have been growing rapidly in recent years. The relations and nature of Ukraine's trade with the EU countries have been analyzed. The conclusions on the development of trade potential after signing the Association Agreement with the EU have been formulated. The assessment of the Complementarity Index of Trade for Ukraine and the EU by 97 commodity groups according to the Ukrainian Classification of Goods for Foreign Economic Activity and the Harmonized Commodity Description and Coding System for 2011-2018 has been carried out. The dynamics of change of complementarity indices are analyzed and the predicted indices of the 
countries for 2019 and 2020 are calculated. It has been proven that mutual trade in a free trade area is mutually beneficial for Ukraine and the EU, as Ukraine and the EU benefit from increased trade, and establishing international partnerships between their businesses and organizations can be particularly beneficial in the long term perspective. It is proposed to deepen international industry cooperation in order to develop competitive advantages and strengthen its position both on the Ukrainian market and the European market.

Keywords. Free trade area, trade complementarity, international economic integration, trade partnership, foreign trade effects.

Анотація. У статті визначені перспективні переваги поглиблення інтеграційних прочесів між Украӥною та Свропейським Союзом. Визначено групи украӥнських товарів, експорт яких до СС активно зростає. Виявлено країни ЄС, до яких стрімко зростає експорт з Украӥни протягом останніх років. Проаналізовано зв'язки, характер торгівлі товарами України з країнами-членами Свропейського Союзу. Сформульовано висновки про розвиток торговельного потенціалу після підписання Угоди про асоиіацію з СС. Проведено оцінку індексу компліментарності торгівлі для України та ЄС за 97 групами товарів згідно УКТЗЕД та Гармонізованої системи опису та кодування товарів для 2011-2018 років. Проаналізовано динаміку зміни індексів та розраховано прогнозні показники індексів країн на 2019 та 2020 роки. Доведено, щчо взаємна торгівля в умовах зони вільної торгівлі $\epsilon$ взаємовигідною для України та ЄС, адже Україна та ЄС виграють від збільшення торгівлі, a встановлення міжнародних партнерських відносин між їх підприємствами та організаціями може бути особливо корисним в довгостроковій перспективі. Запропоновано поглиблювати міжнародну галузеву співпрацю для розвитку конкурентних переваг та посилення свойх позицій як на ринку Украӥни, так і в межах європейського ринку збуту.

Ключові слова. Зона вільної торгівлі, компліментарність торгівлі, міжнародна економічна інтеграція, торговельні партнери, зовнішньоторговельні ефекти.

Аннотация. В статье определены перспективные преимущества углубления интеграционных прочессов между Украиной и Европейским Союзом. Определены группь украинских товаров, экспорт которых в ЕС активно растет. Проанализировань связи, характер торговли товарами Украины со странами-членами Европейского Союза. Сформулированы выводы о развитии торгового потенциала после подписания Соглатения об ассочиачии с ЕС. Выявлено страны EC, в которых стремительно растет экспорт из Украины в последние годы. Проведена оченка индекса комплиментарности торговли для Украины и ЕС за 97 группам товаров согласно УКТВЭД и системы описания и кодирования товаров Всемирной таможенной организаџии для 2011-2018 годов. Проанализирована динамика изменения индексов и рассчитан прогнозные показатели индексов стран на 2019 и 2020 годы. Доказано, что взаимная торговля в условиях зоны свободной торговли является взаимовыгодным для Украины и ЕС, ведь Украина и ЕС выиграют от увеличения торговли, а установление международных партнерских отношений между их предприятиями $u$ организациями может быть особенно полезным в долгосрочной перспективе. Предложено углублять международную отраслевую сотрудничество для развития конкурентных преимуществ и усиления своих позищий как на рынке Украины, так и в пределах европейского рынка сбыта.

Ключевые слова. Зона свободной торговли, комплиментарность торговли, международная экономическая интеграция, торговые партнеры, внешнеторговые эффектыл.

Introduction. European integration processes in Ukraine significantly affect the functioning of the country's economic system. The signing of the Association Agreement has a number of 
economic consequences. Ensuring sustainable development in free trade zone between Ukraine and the EU requires a thorough analysis of the complementarity effect of trade.

The purpose of research. The purpose of this article is to investigate the tendencies in the bilateral complementarity of trade relations between Ukraine and the European Union.

Analysis of the latest publications. The methodology of assessing the complementarity of international trade is described in the work of Andreosso-O'Callaghan B., who studied economic structural complementarity of Korea-EU FTA [O'Callaghan, 2010] and in the work of Chandran S., where trade relations between India and Asian countries under the creation of free trade zone are outlined [Chandran, 2010]. Khadan J. and Hossein R. calculated the complementarity index of trade between Caribbean countries [Khadan and Hossein, 2013]. Shuai C. M. and Wang X. provided empirical analysis of comparative advantages and complementarity of agricultural trade between China and USA [Shuai and Wang, 2011]. Hoang V. studied agricultural trade complementarity of the Association of Southeast Asian Nations [Hoang, 2018]. Vahalík B. provided a thorough analysis of Regional Bilateral Trade of the European Union, China and ASEAN using indices of regional trade intensity and trade complementarity [Vahalík, 2014].

In Ukraine the essence of the concept of "complementarity" is covered in the scientific works of O. Borodina, who studies the methodology and principles of trade complementarity in various spheres of economic research [Borodina, 2015]. N. Dekhtiar provides theoretical recommendations on the estimation of complementarity index, which is related to the country's competitiveness indicators in foreign economic relations [Dekhtiar, 2017].

Ukrainian scientists studied complementarity of trade between Ukraine and the Republic of China as an indicator of the effectiveness of bilateral cooperation (L. Vlasenko [Vlasenko, 2019], Z. Makogin [Makohin, 2012]). V. Panchenko studied the dynamics of the complementarity index after creation of free trade zone between Ukraine and the EU [Panchenko, 2013].

The important research results. The process of economic integration of Ukraine into the world economy is a strategically important aspect of ensuring sustainable growth in the modern economy. The available resource potential of Ukraine is a promising base for the formation and development of progressive forms of competitive advantage of priority sectors of the economy.

The emergence of Ukraine as a full participant in the international arena of trade relations begins with its accession to the WTO in 2008. The next step in this direction was creation of a Deep and Comprehensive Free Trade Area between Ukraine and the European Union, which came into force on January 1, 2016, as well as signing the Association Agreement between Ukraine and the EU (entered into force on September 1, 2017).

Integration processes between Ukraine and the EU have considerable potential for comparable benefits, namely [Klymenko, 2012:]:

- a favorable business environment will be formed in Ukraine as a result of the reforming of national legislation;

- the removal of barriers helps to harmonize the supply and demand balance of trade;

- deepening of inter-state sectoral cooperation will ensure stable mutual development;

- stimulating scientific and technological development helps to form market competition [Fedirko, 2015].

Thanks to the removal of tariff barriers, national enterprises become able to seize the large and stable Eurozone market as well as grow into a participant of public procurement of EU countries [Bilenko, 2015]. In addition, integration processes facilitate the establishment of new business relationships between Ukrainian suppliers and European enterprises and organizations (Figure 1). 
Figure 1

\section{Increase in Ukraine's exports to EU countries (in 2018 compared to 2016)}

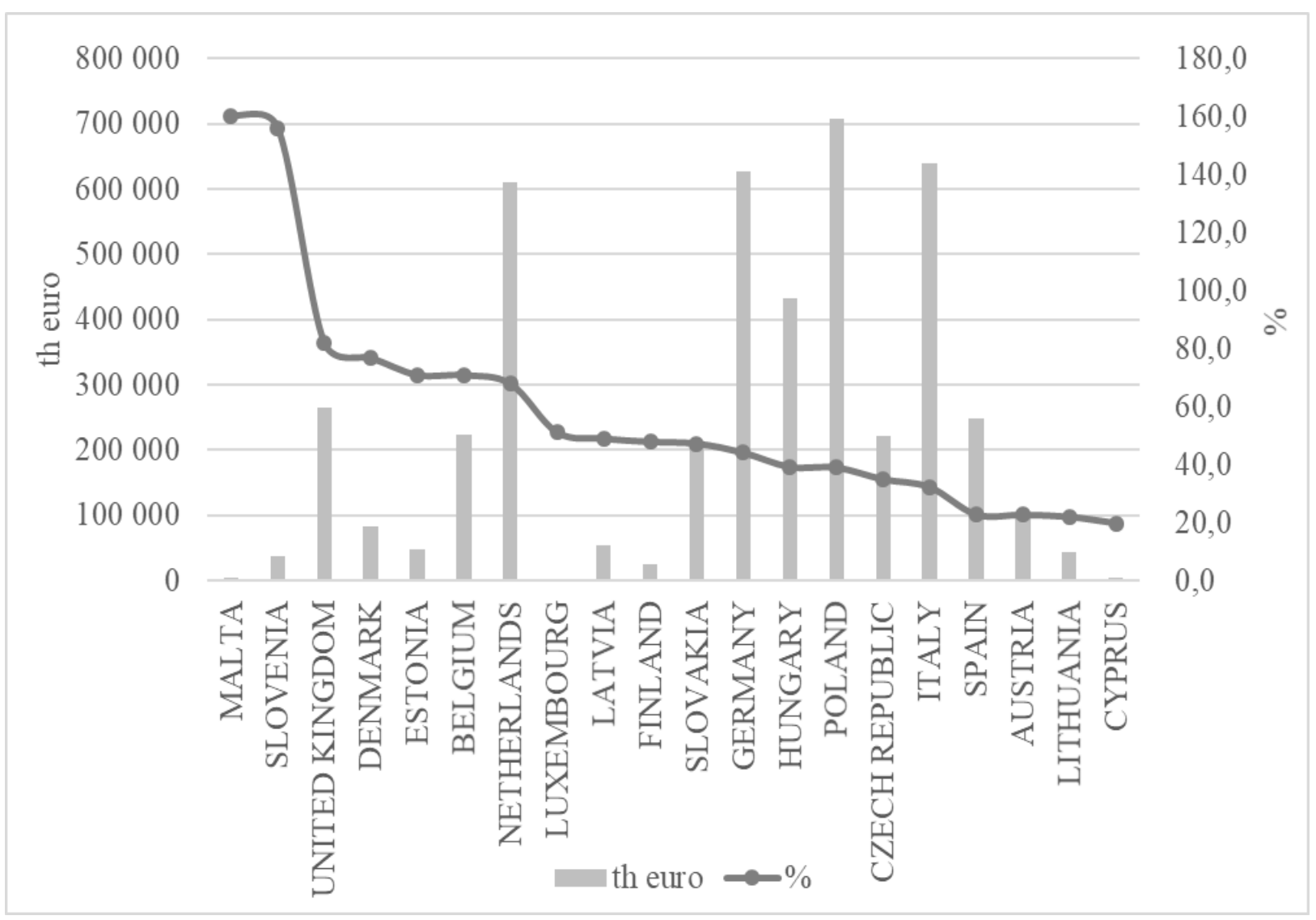

Source: authors' calculations based on [State Statistics Service of Ukraine, 2019].

The signing of the Association Agreement resulted in a dynamic increase in exports of goods from Ukraine to EU countries, namely: Malta (160.3\% growth compared to 2016), Slovenia (156.0\%), the United Kingdom (82.0\%), Denmark (76.8\%), Estonia (70.8\%) and other countries.

Analysis of Ukraine's exports of goods to the EU in 2018 compared to 2016 revealed a significant increase in the following product groups: nickel and by-products by EUR 2.5 million (29 times), zinc by EUR 234 thousand (424\%), vegetables by EUR 67.5 million (316\%), organic chemicals by EUR 164 million (271\%), meat and by-products by EUR 143 million (229\%) and other livestock products by EUR 8.7 million (258\%), and other goods (Fig. 2). At the same time, 5 product groups occupy the highest positions of exports from Ukraine to the EU during 2011-2018, namely: ferrous metals; cereals; electric machines; ores, scales and ash; mineral fuels. 
Increase in exports of Ukrainian goods to the EU (in 2018 compared to 2016)

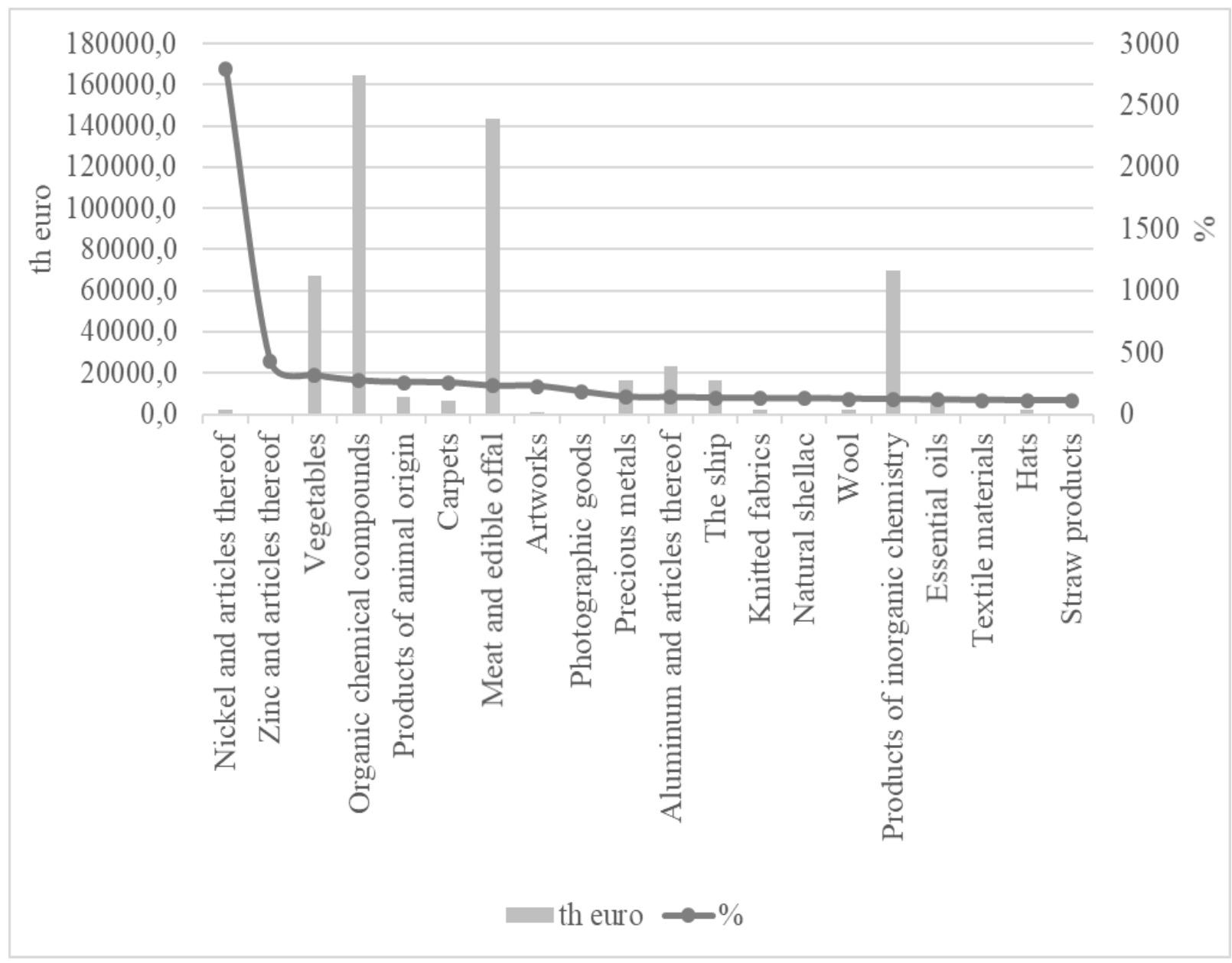

Source: authors' calculations based on [State Statistics Service of Ukraine, 2019]

The European integration vector envisages the emergence of a new concept of doing business, which is the result of expansion of market and increasing of the number of competitors. This increase in the number of participants in economic relations implies the need to develop competitive advantages, that is, the introduction of new production technologies to ensure the high quality of products, which requires significant financial resources [Holikovoi, 2014: 59].

Ukraine's European foreign trade orientation dictates new requirements for doing business that involve forming partnerships with various organizations in EU countries. That is why it is advisable to determine whether the country is a "natural trading partner", which is carried out by the assessment of the complementarity index.

The Complementarity Index is calculated as the sum of the variations in the share of imports of each product by the partner country in the total imports of the country for each product and the shares of exports of each product by the partner country in the total exports of each product:

$$
T C I_{K}=100-\frac{1}{2} \cdot\left(\sum_{i=1}^{n}\left|M_{i}^{P}-X_{i}^{K}\right|\right) ;
$$

where $T C I_{K}$ - complementarity index of country $\mathrm{K}$;

$M_{i}^{P}$ - the ratio of exports of goods from country K to country $\mathrm{P}$ to total imports of goods by country P; 
$X_{i}^{K}$ - the ratio of exports of goods from country $\mathrm{K}$ to country $\mathrm{P}$ to total exports of goods by country K;

$\mathrm{i}$ - the commodity number by the code of foreign economic activity;

$\mathrm{n}$ - total number of goods by the code of foreign economic activity;

$\mathrm{K}$ - country for which the index is calculated;

$\mathrm{P}$ - partner of country K.

The index value is calculated as a percentage from $0 \%$ (indicating absolute lack of complementarity as result of absence of export from country K to country $\mathrm{P}$ ) to $100 \%$ (indicating complete complementarity, which is possible due to the equality between total imports of goods by country $\mathrm{P}$ and total export of goods by country K).

To calculate the Complementarity Index of Ukrainian-European trade relations, official data of the State Statistics Service of Ukraine [State Statistics Service of Ukraine, 2019] and the Statistical Office of the European Union [Statistical Office of the European Union, 2019] for 20112018 is used. The classification list includes 97 commodity groups according to the Ukrainian Classification of Goods for Foreign Economic Activity and the Harmonized Commodity Description and Coding System, on the basis of which the indexes were evaluated (Table 1).

Assessment of mutual complementarity between Ukraine and the EU in 2018

Table 1.

\begin{tabular}{|c|c|c|c|c|c|c|}
\hline & Meu & $\mathbf{X u}$ & Mu & Xeu & $\begin{array}{l}\text { Complementarity } \\
\text { index of Ukraine }\end{array}$ & $\begin{array}{l}\text { Complementarity } \\
\text { index of EU }\end{array}$ \\
\hline 01 live animals & 0.00 & 0.02 & 0.96 & 0.02 & 0.01 & 0.47 \\
\hline $\begin{array}{l}02 \text { Meat and edible } \\
\text { offal }\end{array}$ & 0.05 & 0.36 & 0.87 & 0.01 & 0.16 & 0.43 \\
\hline $\begin{array}{l}03 \text { fish and } \\
\text { crustaceans }\end{array}$ & 0.00 & 0.78 & 0.19 & 0.02 & 0.39 & 0.08 \\
\hline $\begin{array}{l}04 \text { milk and dairy } \\
\text { products, poultry } \\
\text { eggs; natural honey }\end{array}$ & 0.10 & 0.26 & 0.94 & 0.01 & 0.08 & 0.47 \\
\hline $\begin{array}{l}05 \text { other products of } \\
\text { animal origin }\end{array}$ & 0.01 & 1.06 & 0.36 & 0.01 & 0.53 & 0.18 \\
\hline $\begin{array}{l}06 \text { live trees and } \\
\text { other plants }\end{array}$ & 0.00 & 0.30 & 1.62 & 0.02 & 0.15 & 0.80 \\
\hline 07 vegetables & 0.02 & 0.43 & 0.27 & 0.01 & 0.21 & 0.13 \\
\hline $\begin{array}{l}08 \text { Edible fruits and } \\
\text { nuts }\end{array}$ & 0.01 & 0.80 & 0.16 & 0.02 & 0.40 & 0.07 \\
\hline 09 coffee, tea & 0.00 & 0.25 & 0.48 & 0.04 & 0.12 & 0.22 \\
\hline 10 cereals & 0.33 & 0.34 & 0.70 & 0.02 & 0.00 & 0.34 \\
\hline $\begin{array}{l}11 \text { products of the } \\
\text { flour and cereals } \\
\text { industry }\end{array}$ & 0.08 & 0.11 & 0.43 & 0.00 & 0.02 & 0.21 \\
\hline $\begin{array}{l}12 \text { seeds and fruits } \\
\text { of oil plants }\end{array}$ & 0.09 & 0.56 & 0.54 & 0.05 & 0.23 & 0.24 \\
\hline 13 natural shellac & 0.00 & 0.51 & 0.53 & 0.01 & 0.26 & 0.26 \\
\hline $\begin{array}{l}14 \text { vegetable } \\
\text { materials for } \\
\text { manufacture }\end{array}$ & 0.16 & 1.18 & 0.19 & 0.01 & 0.51 & 0.09 \\
\hline $\begin{array}{l}15 \text { Animal or } \\
\text { vegetable fats and } \\
\text { oils }\end{array}$ & 0.10 & 0.25 & 0.21 & 0.01 & 0.08 & 0.10 \\
\hline 16 meat and fish & 0.00 & 0.12 & 0.35 & 0.02 & 0.06 & 0.17 \\
\hline
\end{tabular}




\begin{tabular}{|c|c|c|c|c|c|c|}
\hline & Meu & $\mathbf{X u}$ & Mu & Xeu & $\begin{array}{l}\text { Complementarity } \\
\text { index of Ukraine }\end{array}$ & $\begin{array}{l}\text { Complementarity } \\
\text { index of EU }\end{array}$ \\
\hline \multicolumn{7}{|l|}{ products } \\
\hline $\begin{array}{l}17 \text { sugar and sugar } \\
\text { confectionery }\end{array}$ & 0.03 & 0.15 & 0.53 & 0.01 & 0.06 & 0.26 \\
\hline $\begin{array}{l}18 \text { cocoa and its } \\
\text { products }\end{array}$ & 0.01 & 0.26 & 0.71 & 0.04 & 0.12 & 0.34 \\
\hline $\begin{array}{l}19 \text { finished grain } \\
\text { products }\end{array}$ & 0.04 & 0.30 & 0.71 & 0.01 & 0.13 & 0.35 \\
\hline $\begin{array}{l}20 \text { vegetable } \\
\text { processing products }\end{array}$ & 0.02 & 0.62 & 0.55 & 0.02 & 0.30 & 0.27 \\
\hline 21 different foods & 0.01 & 0.34 & 0.55 & 0.02 & 0.17 & 0.26 \\
\hline $\begin{array}{l}22 \text { alcoholic and } \\
\text { non-alcoholic } \\
\text { beverages and } \\
\text { vinegar }\end{array}$ & 0.01 & 0.17 & 0.52 & 0.01 & 0.08 & 0.26 \\
\hline $\begin{array}{l}23 \text { food industry } \\
\text { residues and wastes }\end{array}$ & 0.05 & 0.47 & 0.77 & 0.03 & 0.21 & 0.37 \\
\hline $\begin{array}{l}24 \text { tobacco and } \\
\text { industrial tobacco } \\
\text { substitutes }\end{array}$ & 0.00 & 0.00 & 0.37 & 0.02 & 0.00 & 0.17 \\
\hline $\begin{array}{l}25 \text { salt; sulfur; earth } \\
\text { and stones }\end{array}$ & 0.06 & 0.74 & 0.23 & 0.02 & 0.34 & 0.11 \\
\hline 26 ore, slag and ash & 0.08 & 0.69 & 0.03 & 0.00 & 0.31 & 0.01 \\
\hline $\begin{array}{l}27 \text { mineral fuels; oil } \\
\text { and its distillation } \\
\text { products }\end{array}$ & 0.00 & 0.78 & 0.19 & 0.02 & 0.39 & 0.08 \\
\hline $\begin{array}{l}28 \text { products of } \\
\text { inorganic chemistry }\end{array}$ & 0.01 & 0.17 & 0.22 & 0.01 & 0.08 & 0.11 \\
\hline $\begin{array}{l}29 \text { organic chemical } \\
\text { compounds }\end{array}$ & 0.00 & 1.12 & 0.27 & 0.00 & 0.56 & 0.13 \\
\hline $\begin{array}{l}30 \text { pharmaceutical } \\
\text { products }\end{array}$ & 0.00 & 0.05 & 0.73 & 0.01 & 0.02 & 0.36 \\
\hline 31 fertilizers & 0.01 & 0.36 & 0.25 & 0.06 & 0.18 & 0.10 \\
\hline$\ldots$ & $\ldots$ & $\ldots$ & $\ldots$ & $\ldots$ & $\ldots$ & $\ldots$ \\
\hline Total & & & & & 79.19 & 72.72 \\
\hline
\end{tabular}

Source: authors' calculations based on [State Statistics Service of Ukraine, 2019; Statistical Office of the European Union, 2019; WBG, 2019; IMF, 2019].

The results of the calculations indicate that Ukraine and the European Union are "natural trading partners". In 2018, EU exports met the needs of the Ukrainian market by $72.72 \%$, and Ukrainian exports met the needs of the EU market in goods by $79.19 \%$. This trend is observed during 2011-2018 (Fig. 4). 


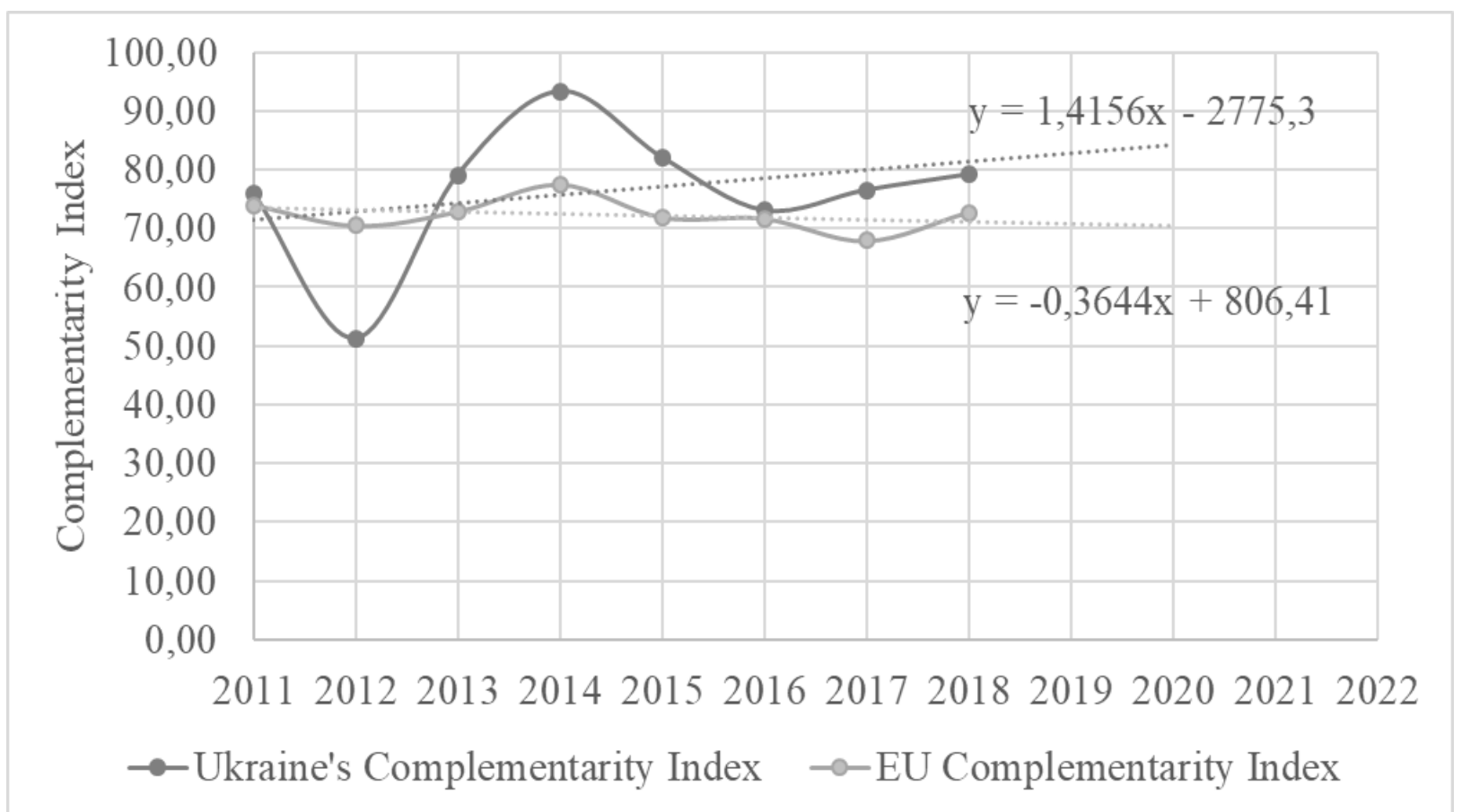

Figure 3. Dynamics of mutual complementarity between Ukraine and the EU during 2011-2018

Source: authors' calculations based on [State Statistics Service of Ukraine, 2019; Statistical Office of the European Union, 2019; WBG, 2019; IMF, 2019].

Based on Fig. 3, we predict similar complementarity indices for 2019 and 2020. According to the linear forecast, in 2019 the complementarity of Ukrainian exports will increase by $3.51 \%$ (will be $82.7 \%$ ), and in 2020 - by $1.41 \%$ (will be $84.11 \%$ ). The complementarity of European exports to Ukrainian imports will be $70.71 \%$ (2.01\% down), and in $2020-70.35 \%$ (0.36\% down).

Thus, mutual trade in a free trade area is beneficial for both partners, as Ukraine and the EU benefit from increased trade, and establishing international partnerships between their businesses and organizations can be particularly beneficial in the long term perspective.

Conclusions. It has been found out that the EU and Ukraine are "natural trading partners", as evidenced by the high level of mutual trade complementarity. The dynamics of Ukraine's complementarity index tend to gradually increase, which is a positive result of signing the Association Agreement with the EU. The creation of a free trade area has contributed to the dynamic growth of exports of nickel, zinc, vegetables, animal products to EU countries such as Malta, Slovenia, the United Kingdom, Denmark, Estonia and others.

Integration processes intensify market competition, which stimulates the development of business entities in Ukraine and takes them to a new level of doing business. Domestic enterprises should focus on developing competitive advantages to strengthen their positions both in the Ukrainian market and the European market, which is possible in the case of close international sectoral cooperation.

\section{References}

1. Біленко Ю. І. (2012) Динамічні ефекти створення зони вільної торгівлі України 3 Свропейським Союзом [Dynamic effects of Ukraine's free trade area with the European Union]. Київ: Актуальні проблеми міжнародних відносин 111(2): 30-39, <http://nbuv.gov.ua/UJRN/apmv_2012_111\%282\%29_6>

2. Бородіна О. С. (2015) Принцип компліментарності в міждисциплінарних дослідженнях економіки [The principle of complementarity in interdisciplinary studies of economics]. Київ: Економіка і прогнозування 2: 47-58, <http://nbuv.gov.ua/UJRN/econprog_2015_2_6> 
3. Галайда Л. В. (2018) Облікові аспекти відображення стану та зміни власного капіталу підприємства [Accounting aspects of the reflection of the state and changes in the equity of the enterprise] Економіка. Фінанси. Менеджмент: актуальні питання науки і практики 1:134-142 <http://nbuv.gov.ua/UJRN/efmapnp_2018_1_13 >

4. Дегтяр Н. А. (2017) Дослідження феномена внутрішньогалузевої торгівлі як чинника конкурентоспроможності країни в зовнішньоекономічних відносинах [Investigation of the phenomenon of intra-industry trade as a factor of the country's competitiveness in foreign economic relations] Biznes-inform 11: 67-74 <nbuv.gov.ua/j-pdf/ binf_2017_11_12>

5. Голівкова Т. В. (2014) Інструменти регулювання просторово-економічного розвитку України [Instruments of regulation of spatial and economic development of Ukraine] Київ: НАН України, ДУ «Ін-т екон. та прогнозув. НАН України»

6. Клименко I. В. Ризики європейського інтеграційного проекту: виклики та можливості для України [Risks of the European integration project: challenges and opportunities for Ukraine] НІСД: 88.

7. Макогін 3. Я. (2012) Комплементарність структури українсько-китайських економічних відносин [Complementarity of the structure of Ukrainian-Chinese economic relations] Науковотехнічна інформація 2: 24-31, <http://nbuv.gov.ua/UJRN/NTI_2012_2_6>

8. Панченко В. Г. (2013) Вплив створення зони вільної торгівлі з СС на економіку України [The impact of the creation of a free trade area with the EU on the economy of Ukraine] Київ: Міжнароднй центр перспективних досліджень: 22-23, <http://icps.com.ua/assets/uploads/files/analitical_research.pdf>

9. Федірко Н. (2015) Макроекономічні ефекти міжнародної регіональної економічної інтеграції: світова практика та виклики для України [Macroeconomic effects of international regional economic integration: world practice and challenges for Ukraine] Міжнародна економічна політика 1: 155-179, http://nbuv.gov.ua/UJRN/Mep_2015_1_9

10. Andreosso-O'Callaghan B. (2009): Economic structural complementarity: how viable is the Korea-EU FTA? Journal of Economic Studies, 36: 147-167

11. Chandran S. (2010) Trade Complementarity and Similarity Between India and Asean Countries in the context of the RTA, https://mpra.ub.uni-muenchen.de/29279/

12. Hoang V. (2018): Assessing the agricultural trade complementarity of the Association of Southeast Asian Nations countries. Agric. Econ. - Czech, 64: 464-475, https://www.agriculturejournals.cz/publicFiles/253_2017-AGRICECON.pdf

13. Khadan J. (2013) New Empirical Insights into the "Natural Trading Partner" Hypothesis for CARICOM Countries. Munich: MPRA Paper, <https://ideas.repec.org/p/pra/mprapa/50493.html>

14. Shuai C.M., Wang X. (2011): Comparative advantages and complementarity of the Sino-US agricultural trade: an empirical analysis. Agricultural Economics - Czech, 57: 118-131

15. Vahalík B. (2014) Regional Bilateral Trade Analysis of the European Union, China and ASEAN. Procedia Economics and Finance 12: 709 - 717, https://core.ac.uk/download/pdf/82500988.pdf

16. Vlasenko L. V. (2019) Complementarity of Trade between Ukraine and the People's Republic of China as an Indicator of the Effectiveness of Bilateral Cooperation; Elektronne naukove fakhove vydannia z ekonomichnykh nauk «Modern Economics» 15, https://modecon.mnau.edu.ua/issue/152019/vlasenko.pdf

17. An official website of the European Union (2019) Database $<$ https://ec.europa.eu/eurostat/web/international-trade-in-goods/data/database>

18. International Monetary Fund (2019) Databases <http://www.imf.org/>

19. State Statistics Service of Ukraine (2019) Statistical Information <http://ukrstat.gov.ua/>

20. The World Bank Group (2019) World Bank Data <http://www.worldbank.org/> 